\title{
PENANGANGAN KONSTIPASI PADA LANSIA DENGAN URUT PERUT DAN LATIHAN ELIMINASI (UPLANASI)
}

\section{[MANAGEMENT OF CONSTIPATION IN ELDERY WITH ABDOMINAL MESSAGE AND TOILET TRAINING OR UPLANASI]}

\author{
Kristamuliana1, Juniati Sahar², Etty Rekawati ${ }^{3}$ \\ Program Studi IImu Keperawatan Fakultas Kedokteran Universitas Sam Ratulangi Manado ${ }^{1}$ \\ Fakultas IImu Keperawatan Universitas Indonesia ${ }^{2,3}$ \\ e-mail : kristamuliana@unsrat.ac.id \\ DOI : 10.47718/jpd.v8i01.893
}

\section{ABSTRAK}

Latar Belakang: Konstipasi merupakn salah satu gangguan sistem pencernaan dan sistem eliminasi yang sering dialami oleh lansia. Hal ini terjadi sebagai akibat dari penurunan fungsi sistem pencernaan dan eliminasi karena proses penuaan. Sekitar $74-45$ \% lansia yang tinggal di PSTW dan sekitar 50\% lansia yang tinggal di komunitas mengalami konstipasi. Tujuan: Penelitian ini bertujuan untuk mengetahui pengaruh uplanasi terhadap konstipasi pada lansia di PSTW di DKI Jakarta. Metode: Desain penelitian yang digunakan adalah quasi experiment pre - post test with control group. Jumlah sampel sebanyak 64 lansia, 32 lansia untuk intervensi dan 32 lansia untuk non-intervesi. Sampel dipilih melalui metode random sampling. Instrumen penelitian yang digunakan adalah Constipation Skoring System. Hasil: Hasil penelitian menunjukkan adanya pengaruh uplanasi terhadap konstipasi pada lansia $(p=0,000)$. Frekuesni defekasi meningkat secara signifikan $(p=0,000)$, lama proses defekasi menurun secara signifikan $(p=0,003)$ dan kenyamanan saat defekasi meningkat secara signifikan $(p=0,000)$. Kesimpulan: Urut perut dan latihan eliminasi layak dijadikan sebagai salah satu intervensi keperawatan untuk menangani masalah konstipasi pada lansia.

Kata Kunci: Urut Perut; Latihan Eliminasi; Lansia; PSTW;

Konstipasi. 


\section{ABSTRACT}

Introduction: Constipation is one of problems in digestive system and elimination system in elderly. Constipation accur because of ageing process. There are $74-75 \%$ elderlies in nursing home and $50 \%$ in community have constipation. Aim: The aims of this research is to know effect of uplanasi in Elderly who live in Nursing homes in DKI Jakarta. Method: Desain of this research was quasi experiment pre - post test with control group. Total samples were 64 elderlies, 32 erderlies for intervension group and 32 elderlies for control group. Samples were choosen by way of random sampling. The instruments that were used in this research were Constipation Scoring System (CSS). Results: The results showed that uplanasi have significant influence to handle constipation in elderly $(p=0,000)$. The uplanasi incrase frequency of defecation $(p=0,000)$, decreasing time of defecation $(p=$ $0,003)$ and increasing comfort during defecation $(p=0,000)$. Conclution: Uplanasi could be one of nursing intervenstions to handle constipation in elderly.

Key words: Uplanasi, elderly, nursing home, constipation

\section{Pertambahan usia pada manusia mengakibarkan terjadinya} penurunan fungsi berbagai sistem dalam tubuh. Salah satunya adalah sistem pensernaan dan eliminasi. Penurunan fungsi sistem pencernaan dan eliminasi salah satunya dapat menyebabkan terjadinya konstipasi.

Prevalensi kejadian konstipasi sebesar 50\% untuk lansia yang tinggal di masyarakatdan 74 - 75\% untuk lansia yang tinggal di Panti Sosial (Clinical Intervention in Aging, 2010, Rogers, 2013).

Di Indonesia khususnya di DKI Jakarta menurut pengkajian Wulandari (2014) di Wisma Cempaka PSTW Budi Mulia 1 Cipayung ditemukan sebanyak 13,7 \% lansia mengalami kontipasi dan 
pengkajian Sari at al (2014) di Wisma Melati PSTW Budi Mulia III

Ciracas ditemukan sebanyak $41,9 \%$ lansia yang mengalam konstipasi.

Tindakan yang sudah dilakukan di Nursing Homes khususnya di Luar Negeri untuk mengurangi konstipasi adalah diet tinggi serat dan pemberian laksatif (Strutzel \& Elmafda 2008; Fosnes, 2012). Tindakan-tindakan tersebut efektif, namun kurang cocok diterapkan di Panti Sosial di Indonesia karena membutuhkan biaya yang besar. Selain itu, pemberian makanan berserat bagi lansia dapat terkendala pada masalah gigi. Penurunan jumlah gigi akibat proses penuaan membuat lansia cenderug menghindari makanan yang sulit dikunya. Sementara itu, penggunaan laksatif yang terlalu sering dapat menyebabkan ketergantungan serta dapat pula menimbulkan diare.

McClurg (2011) melakukan tindakan urut perut pada klien multiple skerosis yang mengalami konstipasi. Sebanyak 15 responden intervensi yang diberikan tindakan urut perut dan nasehat tentang pola hidup dan 15 responden kontrol yang hanya diberikan nasehat tentang pola hidup. Hasil uji statistik sebelum dan setelah tindakan pada kelompok intervensi menunjukkan $p$ value $=0,03(p<0,05)$ dan hasil uji statistik pada kedua kelompok setelah tindakan menunjukkan $p$ value $=0,01(p<0,05)$. Hal ini menunjukkan bahwa ada pengaruh urut perut terhdap konstipasi pada penderita multiple sklerosis. Penelitian ini diperkuat pula oleh Bromley (2013) pada anak dengan disabilitas yang 
mengalami konstipasi. Hasilnya menunjukkan bahwa tindakan ini dapat meningkatkan kualitas hidup klien, mengurangi gejala konstipasi sebesar $87,5 \%$ dan mengurangi penggunaan laksatif sebesar $41 \%$.

Penelitian lain terkait penanganan konstipasi antara lain penelitian Sakakibara et al (2010) tentang pengaruh posisi tubuh terhadap defekasi pada manusia. Hasil penelitian ini menunjukkan bahwa posisi jongkok atau squatty potty yaitu posisi defekasi dengan sudut anorektal yang lebih sempit dapat meningkatkan tekanan pada abdomen dan menyebabkan pembukaan pada rektum sehingga tinja dapat terdorong ke luar.

Penelitian yang sama yang dilakukan oleh Taylor (2014) pada klien yang rata-rata sudah mengalami konstipasi selama 10 12 tahun. Berdasarkan Constipation Scoring System (CSS), hasil penelitian ini menunjukkan bahwa posisi defekasi squatty potty signifikan meringankan masalah konstipasi. Penelitian yang sama yang dilakukan oleh Sikirov (2003) tentang perbedaan kesulitan defekasi pada posisi duduk dan posisi jongkok. Hasilnya menunjukkan bahwa duduk membuat proses defekasi lebih sulit dibandingkan dengan posisi jongkok

\section{METODE PENELITIAN}


melalui proses wawancara dengan responden. Nama responden

tidak dituliskan secara langsung pada lembar kuisioner melainkan hanya menggunakan inisial untuk menjaga privasi responden. Penelitian ini tidak menimbulkan resiko apapun serta mampu menangani masalah konstipasi pada lansia. Tindakanyang dilakukan adalah mengintegrasikan urut perut dan latihan eliminasi. Tindakan ini dalakukan selama 15 hari berutut-turut dan dilakukan evaluasi pada hari ke-16.

Tabel 1. Perbedaan setelah uplanasi pada kelompok intervensi dan non-intervensi

\begin{tabular}{|c|c|c|c|c|c|}
\hline \multirow[t]{2}{*}{ Variabel } & \multicolumn{2}{|c|}{$\begin{array}{c}\text { Intervensi } \\
(n=32)\end{array}$} & \multicolumn{2}{|c|}{$\begin{array}{c}\text { Non-Intervensi } \\
(n=32)\end{array}$} & \multirow[t]{2}{*}{ P Value } \\
\hline & $\mathrm{N}$ & $\%$ & $\mathrm{n}$ & $\%$ & \\
\hline Konstipasi & & & & & 0,000 \\
\hline$-\mathrm{Ya}$ & 1 & 3,1 & 29 & 90,6 & \\
\hline -Tidak & 31 & 96,9 & 3 & 9,4 & \\
\hline Frekuensi Defekasi & & & & & 0,000 \\
\hline -Tidak Normal & 6 & 18,8 & 31 & 96,9 & \\
\hline -Normal & 26 & 81,3 & 1 & 3,1 & \\
\hline Lama defekasi & & & & & 0,003 \\
\hline -Tidak normal & 24 & 75,0 & 32 & 100,0 & \\
\hline -Normal & 8 & 25,0 & 0 & 0,0 & \\
\hline \multicolumn{6}{|l|}{ Kenyamanan } \\
\hline -Tidak Nyaman & 5 & 15,6 & 30 & 93,8 & 0,000 \\
\hline -Nyaman & 27 & 84,4 & 2 & 6,3 & \\
\hline
\end{tabular}

Hasil analisis pada tabel di atas menunjukkan bahwa terjadi perbedaan antara kelompok intervensi dan kelompok nonintervensi setelah tindakan uplanasi. Sebagian besar responden pada kelompok intervensi bebas dari konstipasi, memiliki 
frekuensi defekasi nomal, kenyamanan saat defekasi, dan beberapa responden memiliki lama proses defekasi normal. Sementara itu, pada kelompok non-intervensi, sebagian besar responden mengalami konstipasi, memiliki frekuensi dan lama defekasi yang tidak normal serta ketidaknyamanan saat defekasi. Hasil uji statistik Mann Whitney Test menunjukkan $(p<0,05)$ yang artinya bahwa ada perbedaan yang signifikan mengenai konstipasi, frekuensi defekasi, lama proses defekasi dan kenyamanan saat defekasi pada kelompok intervensi dan nonintervensi setelah tindakan uplanasi.

Hasil penelitian ini sama dengan penelitian yang dilakukan oleh McClurg (2010) yang melakukan urut perut pada klien multiple skerosis. Sebanyak 15 responden intervensi yang diberikan tindakan urut perut dan nasehat tentang pola hidup dan 15 responden kontrol yang hanya diberikan nasehat tentang pola hidup. Hasilnya menunjukkan bahwa ada pengaruh urut perut terhdap konstipasi pada penderita multiple sklerosis. Penelitian ini diperkuat pula oleh Bromley (2013) pada anak dengan disabilitas yang mengalami konstipasi. Hasilnya menunjukkan bahwa tindakan ini dapat meningkatkan kualitas hidup klien, mengurangi gejala konstipasi dan mengurangi penggunaan laksatif.

Terkait latihan eliminasi yang juga merupakan bagian dari uplanasi, penelitian ini sesuai dengan Sakakibara et al (2010) yang meneliti tentang pengaruh posisi defekasi terhadap proses defekasi. Salah satu hasilnya menunjukkan bahwa posisi duduk 
normal dan posisi jongkok memiliki perbedaan yang signifikan dalam meningkatkan tekanan abdomen sehingga dapat membantu mobilisasi tinja dari usus ke rektum. Penelitian ini didukung juga oleh penelitian yang dilakukan oleh Taylor (2014) pada klien yang rata-rata sudah mengalami konstipasi selama 10 12 tahun. Berdasarkan Constipation Scoring System (CSS), hasil penelitian ini menunjukkan bahwa posisi defekasi squatty potty signifikan meringankan masalah konstipasi

Keunikan dari penelitian ini adalah tindakan yang dilakukan pada responden diintegrasikan antara urut perut dan latihan eliminasi. Penelitian-penelitian sebelumnya tidak ada yang menginegrasikan kedua tindakan tersebut. Oleh karena itu, peneliti berasumsi bahwa uplanasi lebih signifikan menangani maslah konstipasi daripada hanya urut perut dan/atau hanya latihan elimiasi. Hal ini dibuktikan dengan nilai $\mathrm{p}$ value penelitian ini lebih kecil daripada penelitian sebelumnya.

\section{KESIMPULAN}

\section{Kesimpulan dari penelitian ini adalah Uplanasi berpengaruh} terhadap konstipasi dengan meningatkan frekuensi defekasi, mengurangi lama proses defekasi dan meningkatkan kenyamanan saat defekasi.

Hasil penelitian ini dapat dijadikan sebagai salah satu terapi keperawatan kompementer untuk penanganan konstipasi utamanya pada lansia di PSTW. Untuk peneliti selanjutnya diharapkan lebih konsisten terhadap waktu dan lama tindakan, mengontrol hal-hal yang mungkin bisa mempengaruhi proses 


\section{DAFTAR PUSTAKA}

defekasi responden seperti kondisi lingkungan. Kondisi lingkungan yang dimaksdu seperti kebersihan toilet, kebiasaan defekasi lansia sebelum tinggal di PSTW, privasi lansia, dan lain-lain

Clinical Interventions in Aging. (2010). Update on the Management of Constipation in the Erderly: New Treatment Options. www.dovepress.com

Rogers, June. (2014). Management of Constipation in the Community. Journal of Community Nursing March/April 2013, volume 27 , issue 2 .

Sturtzel, Bärbel \& Elmadfa, Ibrahim. (2008). Intervention with Dietary Fiber to Treat Constipation and Reduce Laxative Use in Residents of Nursing Homes. Ann Nutr Metab 2008;52(suppl 1):54-56 DOI: 10.1159/000115351

Wulandari, Septiana. (2014). Analisis Praktik Klinik Keperawatankesehatan Masyarakat Perkotaan Pada Bapak B(78 Tahun) Dengan Masalah Konstipasi Di Wisma Cempaka PSTW Budi Mulia I Cipayung. Depok: Perpustaaan UI.

McClurg, Doreen et al. (2011). Abdominal Massage for the Alleviation of Constipation Symptoms in People With Multiple Sclerosis: A Randomized Controlled Feasibility Study. Multiple Sclerosis Journal 17(2) 223-233! The Author(s) 2011 Reprints and permissions: sagepub.co.uk/journals Permissions.nav DOI: 10.1177/1352458510384899 msj.sagepub.com

Bromley, Debbie. (2014). Abdominasl Massage In The Management of Chronic Constipastion for Children with disability. Community Practitioner; Dec 2014; 87, 12

Sakakibara, R. et al. (2010) Influence Of Body Position On Defecation In Humans. Sakura Medical Centre, Toho University 
Volume 08 No.01, Juli 2020 e-ISSN : 26559382 p-ISSN : 22524843
Kristamuliana dkk

Taylor, Gregory S. (2014). New Research: Squatty Potty Reduces Severity of Constipation: Participants Experience Relief Within 1-Month. ST. GEORGE, Utah, June 4, 2014 /PRNewswire/

Sikirov, Dov. (2003). Comparasion of Straining During Defecation in Three Positions. Digestive Diseases and Sciences, Vol. 48, No. 7 (July 2003), pp. 1201-1205 